\title{
PENDIDIKAN KARAKTER: UPAYA MEMBENTUK GENERASI BERKESADARAN MORAL
}

\author{
Much. Arif Saiful Anam \\ (Mahasiswa FTK UIN Sunan Ampel Surabaya)
}

\begin{abstract}
:
The post-reform moral crisis shows that the achievement of moral competence processed at school has not been able to result the optimal output to the moral awareness generation development of nation. This condition such that begun from verbalistic growth culture from the learning process which inclines to only teach moral education as the textual limitation. That phenomenon and fact cause many sides conclude that the importance of character education implementation intensively as the essence of moral awareness generation development. This perspective places moral as the main environment aspect which decides generation characterization. Therefore, moral awareness should be learned intently and progressed or developed by character education applicatively. When the first time of implementation of character education in the school environment, it needs to do by the moral conditioning then continue to the moral training. The Design Character education like this has a function as systemic moral ideas in progressing the generation moral awareness which is able to supply young generation with moral intelligence competence and character.

(Kondisi krisis moral pasca-reformasi menunjukkan bahwa pencapaian kompetensi moral yang diproses melalui bangku persekolahan belumlah menghasilkan output (keluaran) yang optimal terhadap pengembangan kesadaran moral bagi generasi penerus bangsa. Kondisi
\end{abstract}


demikian diduga berawal dari tumbuhnya budaya verbalistik dari proses pembelajaran yang cenderung mengajarkan pendidikan moral sebatas tekstual saja. Fenomena dan fakta tersebut, menyebabkan banyak pihak menyimpulkan bahwa pentingnya implementasi pendidikan karakter secara intensif sebagai esensi pengembangan generasi yang berkesadaran moral. Perspektif ini menempatkan moral sebagai aspek lingkungan utama yang menentukan karakterisasi generasi penerus bangsa. Oleh karena itu, kesadaran moral harus secara intens diajarkan dan dipelajari serta ditumbuhkembangkan melalui pendidikan karakter secara aplikatif. Pada tahap awal implementasi pendidikan karakter di tingkat persekolahan perlu dilakukan melalui pengondisian moral (moral conditioning) yang kemudian berlanjut dengan latihan moral (moral training). Desain pendidikan karakter seperti ini berfungsi sebagai wahana sistemik dalam pengembangan kesadaran moral yang membekali generasi penerus bangsa dengan kompetensi kecerdasan plus karakter).

Kata Kunci: Pendidikan Karakter, Kesadaran Moral, dan Generasi Bangsa

\section{A. Pendahuluan}

Pendidikan adalah sebuah usaha yang ditempuh oleh manusia dalam rangka memperoleh ilmu yang kemudian dijadikan sebagai dasar untuk bersikap dan berperilaku. Karena itu, pendidikan merupakan salah satu proses pembentukan karakter manusia. Pendidikan bisa juga dikatakan sebagai proses pemanusiaan manusia. Dalam keseluruhan proses yang dilakukan manusia, terjadi proses pendidikan yang akan menghasilkan sikap dan perilaku yang 
akhirnya menjadi watak, kepribadian, atau karakternya. Untuk meraih derajat manusia seutuhnya sangatlah tidak mungkin tanpa melalui proses pendidikan.

Pendidikan juga merupakan usaha masyarakat dan bangsa dalam mempersiapkan generasi muda bagi keberlangsungan kehidupan masyarakat dan bangsa yang lebih baik di masa depan. Keberlangsungan itu ditandai oleh pewarisan budaya dan karakter yang telah dimiliki masyarakat dan bangsa. Dalam proses pendidikan budaya dan karakter bangsa, secara aktif generasi muda mengembangkan potensi diri, melakukan proses internalisasi, dan penghayatan nilainilai menjadi kepribadian mereka dalam bergaul di masyarakat, mengembangkan kehidupan masyarakat yang lebih sejahtera, serta mengembangkan kehidupan bangsa yang bermartabat. ${ }^{1}$

Dalam perkembangannya, pembentukkan karakter pada generasi penerus bangsa itu sudah diupayakan dengan berbagai bentuk dan usaha, namun hingga saat ini belum terlaksana dengan optimal. Hal itu tercermin dari semakin meningkatnya kriminalitas, pelanggaran hak asasi manusia, ketidakadilan hukum, kerusakan lingkungan yang terjadi di berbagai pelosok negeri, pergaulan bebas, pornografi dan pornoaksi, tawuran yang terjadi di kalangan remaja, kekerasan dan kerusuhan, serta korupsi yang kian merambah pada semua sektor kehidupan. Masyarakat Indonesia yang terbiasa dengan kesantunan dalam berperilaku, musyawarah-mufakat dalam menyelesaikan masalah, kearifan lokal yang kaya dengan pluralitas, sikap toleran dan gotong-royong, mulai cenderung berubah menjadi haegemoni kelompok-kelompok yang saling mengalahkan dan berperilaku egois individual. Gambaran

\footnotetext{
${ }^{1}$ Zainuddin, Reformasi Pendidikan: Kritik Kurikulum dan Manajemen Berbasis Sekolah (Yogyakarta: Pustaka Pelajar, 2008), 33-34.

Jurnal Pendidikan Agama Islam

Volume 02 Nomor 02 November 2014

Hal $390-426$
} 
fenomena tersebut menunjukkan bangsa ini tengah mengalami krisis moral yang menegaskan terjadinya ketidakpastian jati diri dan karakter generasi penerus bangsanya.

Krisis moral yang tengah melanda bangsa ini, mensyaratkan untuk segera dilakukannya rediscovery nilainilai luhur budaya bangsa atau revitalisasi atau semacam invented tradition melalui gerakan nasional yang melibatkan seluruh komponen sebagai konsensus yang lahir dari kesadaran nasional. ${ }^{2}$

Memperhatikan situasi dan kondisi karakter generasi penerus bangsa pasca-reformasi yang dinilai sudah memprihatinkan, seyogyanya seluruh komponen bangsa sepakat untuk menempatkan pembentukan karakter bagi generasi penerus bangsa sebagai prioritas yang utama. Ini berarti setiap upaya pembentukan tersebut harus selalu dipikirkan keterkaitan dan dampaknya terhadap pengembangan karakterisasi generasi penerus bangsa tersebut. Pemerintah reformasi memang telah merumuskan misi pembangunan nasional yang memposisikan pendidikan karakter sebagai misi pertama dari delapan misi guna mewujudkan visi pembangunan nasional. Hal ini sebagaimana tercantum dalam Rencana Pembangunan Jangka Panjang Nasional Tahun 2005-2025 (Sekretariat Negara Republik Indonesia, 2007),3 yakni terwujudnya karakter bangsa yang tangguh, kompetitif, berakhlak mulia, dan bermoral berdasarkan Pancasila, yang dicirikan dengan watak dan perilaku manusia dan masyarakat Indonesia yang beragam,

\footnotetext{
${ }^{2}$ E.J. Hobsbawm, The Invention of Tradition (New York: Cambridge University Press, 1983), 1.

${ }^{3}$ Sekretariat Negara Republik Indonesia, Undang-Undang RI Nomor 17 Tahun 2007 tentang Rencana Pembangunan Jangka Panjang 2005-2025 (Jakarta: Sekretariat Negara RI, 2007), Bab IV: tentang Arahan, Tahapan, dan PrioritasPembangunan Jangka Panjang 2005-2025, 45.
} 
beriman dan bertakwa kepada Tuhan Yang Maha Esa, berbudi luhur, bertoleran, bergotong-royong, berjiwa patriotik, berkembang dinamis, dan berorientasi pada Ipteks (Kemko Kesejahteraan Rakyat Republik Indonesia, 2010). ${ }^{4}$ Implikasi dari pembentukkan karakter ini sangat luas dan bersifat multidimensional. Sangat luas karena terkait dengan pengembangan multiaspek potensi-potensi keunggulan generasi penerus bangsa, dan bersifat multidimensional karena mencakup dimensi-dimensi kebangsaan yang hingga saat ini sedang dalam proses "menjadi".

Pembentukan karakter generasi penerus bangsa harus diaktualisasikan secara nyata dalam bentuk aksi nasional dalam rangka memantapkan landasan spiritual, moral, dan etika. Pembentukan karakter ini harus dilakukan melalui pendekatan sistematik, integratif dan berkelanjutan. Strategi pembangunan karakter dapat dilakukan melalui sosialisasi, enkulturasi dan internalisasi melalui berbagai institusi dengan memperhatikan kondisi lingkungan dan kebutuhan masyarakat serta pendekatan multidisiplin yang tidak menekankan pada indoktrinasi.

Tanpa bermaksud mengucilkan arti institusi yang lain, pendidikan sebagai institusi masih dinilai layak sebagai wahana sistemik dalam membangun karakter anak bangsa untuk menjadi generasi yang berkesdaran moral. Namun sayang, puluhan tahun kepercayaan publik terhadap institusi pendidikan (pendidikan formal) sebagai wahana sistemik pembentuk karakter anak bangsa, ternyata belum memberikan output yang optimal terhadap pembentukan karakter generasi penerus bangsa. Hal ini diduga pendidikan saat ini lebih cenderung mementingkan pencapaian kompetensi akademik

${ }^{4}$ Kemko Kesejahteraan Rakyat, Kebijakan Nasional Pembangunan Karakter Bangsa (Jakarta: Kemko Kesejahteraan Rakyat, 2010).

Jurnal Pendidikan Agama Islam

Volume 02 Nomor 02 November 2014

Hal $392-426$ 
ketimbang pencapaian kompetensi karakter. Untuk itu usulan adanya pendidikan karakter yang teraktualisasikan secara integralistik sebagai wahana sistemik pengembangan kesadaran moral generasi penerus bangsa, perlu mendapat dukungan berbagai pihak dalam menghasilkan output generasi penerus bangsa yang memiliki kompetensi kecerdasan plus karakter serta berkesadaran moral. 5

\section{B. Hakikat Pendidikan Karakter}

Istilah karakter adalah istilah yang baru digunakan dalam wacana Indonesia dalam lima tahun terakhir ini. Istilah ini sering dihubungkan dengan istilah akhlak, etika, moral, atau nilai. Karakter juga sering dikaitkan dengan masalah kepribadian, atau paling tidak ada hubungan yang cukup erat antara karakter dengan kepribadian seseorang.

Secara etimologis, kata karakter (Inggris: character) berasal dari bahasa Yunani (Greek), yaitu charassein yang berarti "to engrave"6. Kata "to engrave" bisa diterjemahkan mengukir, melukis, memahatkan, atau menggoreskan ${ }^{7}$ seperti orang yang melukis kertas, memahat batu atau metal. Berakar dari pengertian yang seperti itu, character kemudian diartikan sebagai tanda atau ciri yang khusus, dan karenanya melahirkan suatu pandangan bahwa karakter adalah 'pola perilaku yang bersifat individual, menunjukan keadaan moral seseorang'. Setelah melewati tahap anak-anak, seseorang memiliki karakter, cara yang dapat diramalkan bahwa karakter

\footnotetext{
5 Abdul Majid dan Dian Andayani, Pendidikan Karakter Perspektif Islam (Bandung: PT. Remaja Rosdakarya, 2012), 2.

${ }^{6}$ Kevin Ryan dan K. E Bohlin, Building Character in Schools: Practical Ways to Bring Moral Instruction to Life (San Francisco: Jossey Bass, 1999), 5.

7 John M. Echols dan Hassan Shadily, Kamus Inggris-Indonesia (Jakarta: Gramedia, 2003), 214.
} 
seseorang berkaitan dengan perilaku yang ada di sekitar dirinya. Dalam Kamus Bahasa Indonesia, kata "karakter" diartikan dengan tabiat, sifat-sifat kejiwaan, akhlak atau budi pekerti yang membedakan seseorang dengan yang lain, dan watak. Karakter juga bisa berarti huruf, angka, ruang, simbol khusus yang dapat dimunculkan pada layar dengan papan ketik $^{8}$. Orang berkarakter berarti orang yang berkepribadian, berperilaku, bersifat, bertabiat, atau berwatak. Dengan demikian, karakter merupakan watak dan sifat-sifat seseorang yang menjadi dasar untuk membedakan seseorang dari yang lainnya. ${ }^{9}$

Dengan makna seperti itu karakter identik dengan kepribadian atau akhlak. Kepribadian merupakan ciri, karakteristik, atau sifat khas diri seseorang yang bersumber dari bentukan-bentukan yang diterima dari lingkungan, misalnya keluarga pada masa kecil dan bawaan sejak lahir ${ }^{10}$. Seiring dengan pengertian ini, ada sekelompok orang yang berpendapat bahwa baik buruknya karakter manusia sudah menjadi bawaan dari lahir. Jika bawaannya baik, manusia itu akan berkarakter baik, dan sebaliknya jika bawaannya jelek, manusia itu akan berkarakter jelek. Jika pendapat ini benar, pendidikan karakter tidak ada gunanya karena tidak akan mungkin mengubah karakter orang yang sudah taken for granted. Sementara itu, sekelompok orang yang lain berpendapat berbeda, yakni bahwa karakter bisa dibentuk dan

\footnotetext{
${ }^{8}$ Pusat Bahasa Depdiknas, Kamus Bahasa Indonesia (Jakarta: Pusat Bahasa, 2008), 639. Lihat juga Muclas Samani, dan Hariyanto, Konsep dan Model Pendidikan Karakter (Bandung: PT. Remaja Rosdakarya, 2012), 42.

9 Suyadi, Strategi Pembelajarn Pendidikan Karakter (Bandung: PT Remaja Rosdakarya, 2013), 5.

${ }^{10}$ Doni A. Koesoema, Pendidikan Karakter: Strategi Mendidik Anak di Zaman Global (Jakarta: Grasindo, 2007), 80. Lihat juga Masnur Muslich, Pendidikan Karakter: Menjawab Tantangan Krisis Multidimensional (Jakarta: PT. Bumi Aksara, 2011), 70.
}

Jurnal Pendidikan Agama Islam

Volume 02 Nomor 02 November 2014

Hal 394 - 426 
diupayakan sehingga pendidikan karakter menjadi bermakna untuk membawa manusia dapat berkarakter yang baik.

Adapun Secara terminologis, makna karakter dikemukakan oleh Thomas Lickona yang mendefinisikan karakter sebagai "A reliable inner disposition to respond to situations in a morally good way." Selanjutnya, Lickona menambahkan, "Character so conceived has three interrelated parts: moral knowing, moral feeling, and moral behavior"11. Karakter mulia (good character), dalam pandangan Lickona, meliputi pengetahuan tentang kebaikan (moral khowing), lalu menimbulkan komitmen (niat) terhadap kebaikan (moral feeling), dan akhirnya benar-benar melakukan kebaikan (moral behavior). Dengan kata lain, karakter mengacu kepada serangkaian pengetahuan (cognitives), sikap (attitudes), dan motivasi (motivations), serta perilaku (behaviors) dan keterampilan (skills). ${ }^{12}$

Lain halnya Lickona, Hornby dan Parnwell berpendapat bahwa karakter adalah kualitas mental atau moral, kekuatan moral, nama atau reputasi. Hermawan Kertajaya mendefinisikan karakter sebagai "ciri khas" yang dimiliki oleh suatu benda atau individu. Ciri khas tersebut adalah "asli" dan mengakar pada kepribadian benda atau individu tersebut dan merupakan "mesin" pendorong bagaimana orang bertindak, bersikap, berujar, dan merespon sesuatu. ${ }^{13}$

Dalam proses perkembangan dan pembentukan, karakter seseorang dipengaruhi oleh dua faktor, yaitu factor lingkungan (nurture) dan faktor bawaan (nature). Secara psikologis, perilaku berkarakter merupakan perwujudan dari

\footnotetext{
${ }^{11}$ Thomas Lickona, Educating for Character: How Our School Can Teach Respect and Responsibility (New York: Bantam Books, 1991), 51.

${ }^{12}$ Suyadi, Strategi Pembelajarn Pendidikan Karakter , 5.

${ }^{13}$ Abdul Majid dan Dian Andayani, Pendidikan Karakter Perspektif Islam, 11.
} 
potensi Intelligence Quotient (IQ), Emotional Quotient (EQ), Spiritual Quotient (SQ), dan Adverse Quotient (AQ) yang dimiliki oleh seseorang. Konfigurasi karakter dalam konteks totalitas proses psikologis dan sosio-kultural pada akhirnya dapat dikelompokkan dalam empat kategori, yakni 1) olah hati (spiritual and emotional development); 2) olah pikir (intellectual development); 3) olah raga dan kinestetik (physical and kinesthetic development); dan 4) olah rasa dan karsa (affective and creativity development). Keempat proses psiko-sosial ini secara holistic dan koheren saling terkait dan saling melengkapi dalam rangka pembentukan karakter dan perwujudan nilai-nilai luhur dalam diri seseorang ${ }^{14}$.

Oleh karena itu, karakter dapat dipahami sebagai nilainilai yang khas-baik (tahu nilai kebaikan, mau berbuat baik nyata berkehidupan baik, dan berdampak baik terhadap lingkungan) yang terpateri dalam diri dan terejawantahkan dalam perilaku. Secara koheren, karakter memancar dari hasil olah pikir, olah hati, olah raga, serta olah rasa dan karsa seseorang atau sekelompok orang. Karakter merupakan ciri khas seseorang atau sekelompok terwujud dalam pikiran, sikap, perasaan, perkataan, dan perbuatan berdasarkan normanorma agama, hukum, tata karma, budaya, dan adat istiadat. Menurut Amin bahwa kehendak (niat) merupakan awal terjadinya akhlak (karakter) pada diri seseorang, jika kehendak itu diwujudkan dalam bentuk pembiasaan sikap dan perilaku. Dari konsep karakter inilah kemudian muncul konsep pendidikan karakter (character education). ${ }^{15}$

14 Kemdiknas, Desain Induk Pendidikan Karakter (Jakarta: Kementerian Pendidikan Nasional, 2010), 9-10.

15 Ahmad Amin, Etika (Ilmu Akhlak).Farid Ma'ruf (Penerj.) (Jakarta: Bulan Bintang, 1995), 62. Lihat juga Suyadi, Strategi Pembelajarn Pendidikan Karakter, 6. 
Secara sederhana, pendidikan karakter dapat didefinisikan sebagai segala usaha yang dapat dilakukan untuk mempengaruhi karakter siswa.16 Dalam perkembangnya, terminologi pendidikan karakter mulai dikenalkan sejak tahun 1900-an. Thomas Lickona dianggap sebagai pengusung, terutama ketika ia menulis buku yang berjudul Educating for Character: How Our School Can Teach Respect and Responsibility (1991) yang kemudian disusul oleh tulisan-tulisan lain, seperti The Return of Character Education yang dimuat dalam jurnal Educational Leadership (November 1993) dan juga artikel yang berjudul Eleven Principles of Effective Character Education, yang dimuat dalam Journal of Moral Volume 25 (1996). Melalui buku dan tulisan-tulisan tersebut, ia menyadarkan dunia Barat akan pentingnya pendidikan karakter. Pendidikan karakter menurutnya mengandung tiga unsur pokok, yaitu mengetahui kebaikan (knowing the good), mencintai kebaikan (desiring the good), dan melakukan kebaikan (doing the good) ${ }^{17}$. Lebih lanjut Thomas Lickona menyatakan bahwa pendidikan karakter adalah suatu usaha yang disengaja untuk membantu seseorang sehingga ia dapat memahami, memperhatikan, dan melakukan nilai-nilai etika yang inti. Bertitik tolak dari definisi tersebut, ketika kita berpikir tentang jenis karakter yang ingin kita bangun pada diri para siswa, jelaslah bahwa ketika itu kita menghendaki agar mereka mampu memahami nilai-nilai tersebut, memperhatikan secara lebih mendalam mengenai benarnya nilai-nilai itu, dan kemudian melakukan apa yang diyakininya itu, sekalipun harus menghadapi tantangan dan

\footnotetext{
${ }^{16}$ Muclas Samani, dan Hariyanto, Konsep dan Model Pendidikan Karakter, 44.

${ }^{17}$ Thomas Lickona, Educating for Character: How Our School Can Teach Respect and Responsibility, 51. Lihat juga Abdul Majid dan Dian Andayani, Pendidikan Karakter Perspektif Islam,11. Masnur Muslich, Pendidikan Karakter: Menjawab Tantangan Krisis Multidimensional, 133. Suyadi, Strategi Pembelajarn Pendidikan Karakter,6.
} 
tekanan baik dari luar maupun dari dalam dirinya. Dengan kata lain mereka memiliki 'kesadaran untuk memaksa diri' melakukan nilai-nilai itu.

Implikasi dari pengertian Lickona di atas memperlihatkan adanya proses perkembangan yang melibatkan pengetahuan (moral knowing), perasaan (moral feeling), dan tindakan (moral action), sekaligus juga memberikan dasar yang kuat untuk membangun pendidikan karakter yang koheren dan komprehensif. Definisi di atas juga menekankan bahwa kita harus mengikat para subjek didik dengan kegiatan-kegiatan yang akan mengantarkan mereka berpikir kritis mengenai persoalan-persoalan etika dan moral; menginspirasi mereka untuk setia dan loyal dengan tindakantindakan etika dan moral; dan memberikan kesempatan kepada mereka untuk mempraktikkan perilaku etika dan moral tersebut.

Lain halnya Thomas Lickona, Frye mendefinisikan pendidikan karakter sebagai, "A national movement creating schools that foster ethical, responsible, and caring young people by modeling and teaching good character through an emphasis on universal values that we all share".18 Jadi implikasi definisi tersebut adalah bahwa pendidikan karakter harus menjadi gerakan nasional yang menjadikan sekolah (institusi pendidikan) sebagai agen untuk membangun karakter subjek didik melalui pembelajaran dan pemodelan. Melalui pendidikan karakter, sekolah harus berpotensi untuk membawa subjek didik memiliki nilai-nilai karakter mulia, seperti hormat dan peduli pada orang lain, tanggung jawab, jujur, memiliki integritas, disiplin dan berkesadaatran moral. Di sisi lain,

${ }^{18}$ Mike Frye, Character Education: Informational Handbook and Guide for Support and Implementation of the Student Citizent Act of 2001 (North Carolina: Public Schools of North Carolina, 2002), 2.

Jurnal Pendidikan Agama Islam

Volume 02 Nomor 02 November 2014

Hal 398 - 426 
pendidikan karakter juga harus mampu menjauhkan subjek didik dari sikap dan perilaku yang tercela dan dilarang. Pendidikan karakter tidak hanya mengajarkan mana yang benar dan mana yang salah kepada anak. Lebih dari itu, pendidikan karakter menanamkan kebiasaan (habituation) tentang yang baik sehingga subjek didik paham, mampu merasakan, dan mau melakukan yang baik. Dengan demikian, pendidikan karakter membawa misi yang sama dengan pendidikan akhlak atau pendidikan moral. ${ }^{19}$

Dalam Pasal 31 Undang-Undang Dasar Negara Republik Indonesia Tahun 1945, terdapat amanah pada ayat (5) hasil amandemen keempat, yaitu, "Pemerintah memajukan ilmu pengetahuan dan teknologi dengan menjunjung tinggi nilai-nilai agama dan persatuan bangsa untuk kemajuan peradaban serta kesejahteraan umat manusia". Mengacu hal tersebut, berarti pendidikan yang harus dijalankan harus mengandung amanah pencapaian kompetensi (penguasaan IPTEK) dan karakter (menjunjung tinggi nilai-nilai kebajikan). Menurut Salls, Pendidikan karakter adalah proses transformasi nilai-nilai sehingga menimbulkan kebajikan/watak baik (transforming values into virtue). ${ }^{20}$

Lebih lanjut, Wynne mengungkapkan bahwa, istilah karakter diambil dari bahasa Yunani charassein yang berarti mengukir hingga terbentuk pola dan 'to mark' (menandai). Istilah ini lebih fokus pada tindakan atau tingkah laku. Wynne mengatakan bahwa ada dua pengertian tentang karakter. Pertama, ia menunjukkan bagaimana seseorang bertingkah laku. Apabila seseorang berperilaku tidak jujur, kejam, atau

\footnotetext{
${ }^{19}$ E. Mulyasa, Mangemen Pendidikan Karakter (Jakarta: PT Bumi Aksara, 2012), 3.

${ }^{20}$ Holly Shepard Salls, Character Education: An Introduction (New York: University

Press of America, 2007), 87.
} 
rakus, tentulah orang tersebut memanifestasikan perilaku buruk. Sebaliknya, apabila seseorang berperilaku jujur, suka menolong, tentulah orang tersebut memanifestasikan karakter mulia. Kedua, istilah karakter erat kaitannya dengan 'personality'. Seseorang baru bisa disebut 'orang yang berkarakter' (a person of character) apabila tingkah lakunya sesuai kaidah moral. 21

Membangun karakter memerlukan sebuah proses yang simultan dan berkesinambungan yang melibatkan seluruh aspek "knowing the good, loving the good, and acting the good". Di sinilah perbedaannya dengan istilah moral. Pendidikan karakter menjadi berbeda dengan pendidikan moral karena pendidikan moral hanya terfokus pada pengetahuan tentang moral yakni mengajarkan mana yang benar dan mana yang salah (lagi-lagi hanya menekankan aspek kognisi). Sedangakan pendidikan karakter adalah pendidikan untuk membentuk kepribadian seseorang, yaitu menjadi pribadi yang bijaksana, terhormat, dan bertanggung jawab yang hasilnya. terlihat dalam tindakan nyata. Lebih dari itu, Pendidikan karakter menanamkan kebiasaan tentang yang baik sehingga subjek didik menjadi paham, mampu merasakan dan mau melakukan yang baik. ${ }^{22}$ Bagaimana mereka diberi pengetahuan dan pemahaman akan nilai-nilai kebaikan yang universal (knowing the good) sehingga membentuk beliefs, tetapi tidak berhenti di situ saja, sistem yang ada juga berperan aktif mendukung dan mengkondisikan nilai-nilai kebaikan tersebut sehingga semua orang bersepakat menerima dan mencintai nilai-nilai tersebut sebagai sebuah kebaikan untuk dianut (loving the good).

\footnotetext{
21 Masnur Muslich, Pendidikan Karakter: Menjawab Tantangan Krisis Multidimensional, 71. Lihat juga E. Mulyasa, Mangemen Pendidikan Karakter, 34.

${ }^{22}$ Abdul Majid dan Dian Andayani, Pendidikan Karakter Perspektif Islam, 14.

Jurnal Pendidikan Agama Islam

Volume 02 Nomor 02 November 2014

Hal $400-426$
} 
Setelah membentuk pemahaman dan sikap, ia akan melahirkan nilai tindakan-tindakan. Dengan penuh kesadaran mereka akan bertindak dengan nilai-nilai kebaikan (acting the good) yang dianut sebagai ekspresi martabat dan harga diri. Dan apabila nilai-nilai tersebut dilanggar berarti mereka telah kehilangan martabat dan harga diri, dan itu akan membuatnya tidak diterima oleh lingkungan.

Menurut The Character Education Partnership (CEP), pengembangan karakter pada seseorang diperlukan kerjasama antar individu maupun dengan para komunitas. Pendidikan karakter dipandang sebagai proses yang panjang dalam membantu seseorang menemukan karakter yang baik, baik dalam hal pemahaman, kepedulian, maupun tindakan. Sebagai petunjuk bagi para pendidik maupun komunitas, CEP mengembangkan 11 prinsip pendidikan karakter yaitu: (1) Aktif mempromosikan nilai-nilai moral yang inti (agree on and actively promote core ethical values); (2) Membantu seluruh subjek didik memiliki pemahaman, kepedulian, dan tindakan pada nilai-nilai inti (help the hole school understand, care about, and act upon core values); (3) Mencakupkan nilai-nilai inti ke dalam semua tingkatan dalam kehidupan sekolah (Incorporate core values in all phases of school life); (4) Mendorong seluruh subjek didik agar saling memiliki kepedulian (foster caring relationship throughout the school); (5) Memberi kesempatan kepada setiap subjek didik untuk bertindak sesuai moral (offer student opportunities to practice moral behavior); Mengintegrasikan moral dengan akademik/kurikulum (integrate ethics with academic); (7) Mengembangkan motivasi siswa (develop student motivation); (8) Melibatkan seluruh staf di sekolah untuk menjadi model (involve the entire school staff); (9) Menyiapkan pimpinan yang siap bekerja keras (cultivate leaders to champion the effort); (10) Membangun sinergi antara 
sekolah, orang tua maupun komunitas (partner with parents and communities); (11) Melakukan evaluasi terhadap hasil yang selama ini telah diproses (asses result).

Hal ini senada dengan strategi yang dilakukan Lickona dalam pengembangan karakter: (1) strategi pengelolaan kelas (The teacher as caregiver, model, and mentor, $A$ caring classroom community, Character-based discipline, A democratic classroom environment, Teaching character through the curriculum, Cooperative learning, Conscience of craft, Ethical reflection, Teaching conflict resolution), (2) menciptakan lingkungan moral positif di sekolah (Creating a positive moral culture in the school), dan (3) membangun sinergi antara orang tua, sekolah, masyarakat (School, parents, and communities as parents). ${ }^{23}$

\section{Alasan Perlunya Pendidikan Karakter}

Menurut Lickona ada beberapa alasan mengapa pendidikan karakter itu harus disampaikan. Adapun alasanalasan tersebut antara lain sebagai berikut.

1. Merupakan kebutuhan yang jelas dan mendesak.

2. Tidak ada suatu pendidikan yang bebas nilai.

3. Cara terbaik untuk menjamin anak-anak (siswa) memiliki kepribadian yang baik dalam kehidupannya.

4. Cara untuk meningkatkan prestasi akademik.

5. Sebagian siswa tidak dapat membentuk karakter yang kuat bagi dirinya di tempat lain.

\footnotetext{
${ }^{23}$ E.F Schaeffer, It's Time for Schools To Implement Character Education, NASSP Bulletin, 1999, 4. Lihat juga Abdul Majid dan Dian Andayani, Pendidikan Karakter Perspektif Islam, 109. Muclas Samani dan Hariyanto, Konsep dan Model Pendidikan Karakter,168-174. Masnur Muslich, Pendidikan Karakter: Menjawab Tantangan Krisis Multidimensional, 129. E. Mulyasa, Mangemen Pendidikan Karakter,17-18.
}

Jurnal Pendidikan Agama Islam

Volume 02 Nomor 02 November 2014

Hal $402-426$ 
6. Persiapan siswa untuk menghormati pihak atau orang lain dan dapat hidup dalam masyarakat yang beragam.

7. Berangkat dari akar masalah yang berkaitan dengan problem moral-sosial, seperti ketidaksopanan, ketidakjujuran, kekerasan, pelanggaran kegiatan seksual, dan etos kerja (belajar) yang rendah.

8. Persiapan terbaik untuk menyongsong perilaku di tempat kerja.

9. Pembelajaran nilai-nilai budaya yang merupakan bagian dari kerja peradaban.

10. Adanya dukungan yang besar dan luas terhadap pelaksanaan pendidikan moral di sekolah-sekolah. ${ }^{24}$

\section{Fungsi dan Tujuan Pendidikan Karakter}

Pendidikan karakter berfungsi sebagai:

1. Wahana pengembangan, yakni: pengembangan potensi subjek didik untuk menjadi berperilaku yang baik bagi subjek didik yang telah memiliki sikap dan perilaku yang mencerminkan karakter

2. Wahana perbaikan, yakni: memperkuat kiprah pendidikan nasional untuk lebih bertanggungjawab dalam pengembangan potensi subjek didik yang lebih bermartabat, dan

3. Wahana penyaring, yakni: untuk menyaring budaya-budaya bangsa sendiri dan budaya bangsa lain yang tidak sesuai dengan nilai-nilai karakter. ${ }^{25}$

\footnotetext{
${ }^{24}$ Muclas Samani, dan Hariyanto, Konsep dan Model Pendidikan Karakter,13.

${ }^{25}$ Kementrian Pendidikan Nasional Badan Penelitian dan Pengembangan Pusat Kurikulum. Bahan Pelatihan Penguatan Metodologi Pembelajaran Berdasarkan Nilai-Nilai Budaya Untuk Membentuk Daya Saing Dan Karakter Bangsa. Pengembangan Pendidikan dan Karakter Bangsa. (Jakarta: Kemendiknas, 2010), 7. Lihat juga Suyadi, Strategi Pembelajarn Pendidikan Karakter, Bandung, 8-9.
} 
Adapun tujuan pendidikan karakter sebagai berikut:

1. Mengembangkan potensi kalbu/nurani atau afektif subjek didik sebagai manusia dan warganegara yang memiliki nilai-nilai karakter

2. Mengembangkan kebiasaan dan perilaku (habituasi) subjek didik yang terpuji dan sejalan dengan nilai-nilai universal dan tradisi budaya bangsa yang religious

3. Menanamkan jiwa kepemimpinan dan tanggungjawab subjek didik sebagai

4. generasi penerus bangsa

5. Mengembangkan kemampuan subjek didik menjadi manusia yang mandiri, kreatif, berwawasan kebangsaan

6. Mengembangkan lingkungan kehidupan sekolah sebagai lingkungan belajar yang aman, jujur, penuh kreativitas dan persahabatan, serta dengan rasa kebangsaan yang tinggi dan penuh kekuatan (dignity). ${ }^{26}$

\section{E. Nilai-nilai Pendidikan Karakter}

Nilai-nilai yang dikembangkan dalam pendidikan karakter diidentifikasi dari sumber-sumber sebagai berikut:

1. Agama

Masyarakat Indonesia adalah masyarakat beragama. Oleh karena itu kehidupan individu, masyarakat, dan bangsa selalu didasari pada ajaran agama dan kepercayaannya. Secara politis kehidupan kenegaraan pun didasari oleh nilainilai yang berasal dari agama. Atas dasar pertimbangan itu, maka nilai-nilai pendidikan karakter harus didasarkan pada nilai-nilai dan kaidah yang berasal dari agama.

Lihat juga Zubaedi, Desain Pendidikan Karakter Konsepsi dan Aplikasinya dalam Lembaga Pendidikan, (Jakarta: Kencana, 2011), 18.

${ }^{26}$ Ibid., 7.

Jurnal Pendidikan Agama Islam

Volume 02 Nomor 02 November 2014

Hal $404-426$ 
2. Pancasila

Negara Kesatuan Republik Indonesia ditegakkan atas prinsip-prinsip kehidupan kebangsaan dan kenegaraan yang disebut Pancasila. Pancasila terdapat pada Pembukaan UUD 1945 dan dijabarkan lebih lanjut dalam pasal-pasal yang terdapat dalam UUD 1945 tersebut. Artinya, nilai nilai yang terkandung dalam Pancasila menjadi nilai-nilai yang mengatur kehidupan politik, hukum, ekonomi, kemasyarakatan, budaya, dan seni yang diatur dalam pasalpasal UUD 1945. Pendidikan karakter bertujuan mempersiapkan subjek didik menjadi warga negara yang lebih baik, yaitu warga negara yang memiliki kemampuan, kemauan, dan menerapkan nilai-nilai Pancasila dalam kehidupannya sebagai warga negara.

3. Budaya

Adalah suatu kebenaran bahwa tidak ada manusia yang hidup bermasyarakat yang tidak didasari oleh nilainilai budaya yang diakui masyarakat tersebut. Nilai-nilai budaya tersebut dijadikan dasar dalam memberi makna terhadap suatu konsep dan arti dalam komunikasi antaranggota masyarakat tersebut. Posisi budaya yang demikian penting dalam kehidupan masyarakat mengharuskan budaya menjadi sumber nilai- nilai dari pendidikan karakter.

4. Tujuan Pendidikan Nasional

Tujuan pendidikan nasional mencerminkan kualitas yang harus dimiliki setiap warga negara Indonesia, dikembangkan oleh berbagai satuan pendidikan di berbagai jenjang dan jalur. Dalam tujuan pendidikan nasional terdapat berbagai nilai kemanusiaan yang harus dimiliki 
seorang warga negara Indonesia. Oleh karena itu, tujuan Pendidikan nasional adalah sumber yang paling operasional dalam pengembangan pendidikan karakter dibandingkan ketiga sumber yang disebutkan di atas ${ }^{27}$.

Berdasarkan keempat sumber nilai tersebut maka teridentifikasi sejumlah nilai untuk pendidikan karakter sebagai berikut ini:

\section{Tabel 1:}

Deskripsi Nilai Pendidikan Budaya dan Karakter Bangsa. ${ }^{28}$

\begin{tabular}{|l|l|l|}
\hline No. & Nilai & Deskripsi \\
\hline 1. & Religius & $\begin{array}{l}\text { Sikap dan Perilaku yang patuh dalam } \\
\text { melaksnakan ajaran agama yang dianutnya, } \\
\text { toleran terhadap pelaksanaan ibadah agama } \\
\text { lain, dan hidup rukun dengan pemeluk agama } \\
\text { lain }\end{array}$ \\
\hline 2. & Jujur & $\begin{array}{l}\text { Perilaku yang didasarkan pada upaya } \\
\text { menjadikan dirinya sebagai orang yang selalu } \\
\text { dapat dipercaya dalam perkataan, tindakan, } \\
\text { dan pekerjaan. }\end{array}$ \\
\hline 3. & Toleransi & $\begin{array}{l}\text { Sikap dan tindakan yang menghargai } \\
\text { perbedaan agama, suku, etnis, pendapat, sikap } \\
\text { dan tindakan orang lain yang berbeda dari } \\
\text { dirinya }\end{array}$ \\
\hline 4. & Disiplin & $\begin{array}{l}\text { Tindakan yang menunjukkan perilaku tertib } \\
\text { dan patuh pada berbagai ketentuan dan } \\
\text { peraturan }\end{array}$ \\
\hline
\end{tabular}

${ }^{27}$ Kementrian Pendidikan Nasional Badan Penelitian dan Pengembangan Pusat Kurikulum. Bahan Pelatihan Penguatan Metodologi Pembelajaran Berdasarkan Nilai-Nilai Budaya Untuk Membentuk Daya Saing Dan Karakter Bangsa. Pengembangan Pendidikan dan Karakter Bangsa., 7-8.

${ }_{28}^{28}$ Ibid., 9-10. Lihat juga Abdul Majid dan Dian Andayani, Pendidikan Karakter Perspektif Islam, 42-43.

Jurnal Pendidikan Agama Islam

Volume 02 Nomor 02 November 2014

Hal $406-426$ 


\begin{tabular}{|c|c|c|}
\hline 5. & Kerja keras & $\begin{array}{l}\text { Perilaku yang menunjukkan upaya sungguh- } \\
\text { sungguh dalam mengatasi berbagai hambatan } \\
\text { belajar dan tugas serta menyelesaikan tugas } \\
\text { dengan sebaik-baiknya }\end{array}$ \\
\hline 6. & Kreatif & $\begin{array}{l}\text { Berpikir/melakukan sesuatu yang } \\
\text { menghasilkan cara atau hasil baru berdasarkan } \\
\text { apa yang dimiliki }\end{array}$ \\
\hline 7. & Mandiri & $\begin{array}{l}\text { Sikap dan prilaku yang tidak mudah tergantung } \\
\text { pada orang lain dalam menyelesaikan tugas- } \\
\text { tugas }\end{array}$ \\
\hline 8. & Demokratis & $\begin{array}{l}\text { Cara berfikir, bersikap dan bertindak yang } \\
\text { menilai sama hak dan kewajiban dirinya dan } \\
\text { orang lain }\end{array}$ \\
\hline 9. & Rasa ingin tahu & $\begin{array}{l}\text { Sikap dan tindakan yang selalu berupaya untuk } \\
\text { mengetahui lebih mendalam dan meluas dari } \\
\text { apa yang dipelajarinya, dilihat, dan didengar }\end{array}$ \\
\hline 10. & $\begin{array}{l}\text { Semangat } \\
\text { kebangsaan }\end{array}$ & $\begin{array}{l}\text { Cara berpikir, bertindak, dan wawasan yang } \\
\text { menempatkan kepentingan bangsa dan negara } \\
\text { di atas kepentingan diri dan kelompoknya }\end{array}$ \\
\hline 11. & Cinta tanah air & $\begin{array}{l}\text { Cara berfikir, bersikap dan berbuat yang } \\
\text { menunjukkan kesetiaan, kepedulian, dan } \\
\text { penghargaan yang tinggi terhadap bahasa, } \\
\text { lingkungan fisik, sosial, budaya, ekonomi, dan } \\
\text { politik bangsanya. }\end{array}$ \\
\hline 12. & $\begin{array}{l}\text { Menghargai } \\
\text { prestasi }\end{array}$ & $\begin{array}{l}\text { Sikap dan tindakan yang mendorong dirinya } \\
\text { untuk menghasilkan sesuatu yang berguna bagi } \\
\text { masyarakat, dan mengakui dan menghormati } \\
\text { keberhasilan orang lain. }\end{array}$ \\
\hline 13. & $\begin{array}{l}\text { Bersahabat/ } \\
\text { Komunikatif }\end{array}$ & $\begin{array}{l}\text { Tindakan yang memperlihatkan rasa senang } \\
\text { berbicara, bergaul, bekerjasama dengan orang } \\
\text { lain. }\end{array}$ \\
\hline 14. & Cinta damai & $\begin{array}{l}\text { Sikap, perkataan dan tindakan yang } \\
\text { menyebabkan orang lain merasa senang dan } \\
\text { aman atas kehadiran dirinya }\end{array}$ \\
\hline 15. & Senang membaca & $\begin{array}{l}\text { Kebiasaan menyediakan waktu untuk } \\
\text { membaca berbagai bacaan yang memberikan } \\
\text { kebajikan bagi dirinya. }\end{array}$ \\
\hline
\end{tabular}




\begin{tabular}{|l|l|l|}
\hline 16. & Peduli sosial & $\begin{array}{l}\text { Sikap dan tindakan yang selalu ingin memberi } \\
\text { bantuan kepada orang lain yang } \\
\text { membutuhkan }\end{array}$ \\
\hline 17. & $\begin{array}{l}\text { Peduli } \\
\text { lingkungan }\end{array}$ & $\begin{array}{l}\text { Sikap dan tindakan yang selalu berupaya } \\
\text { mencegah kerusakan lingkungan alam di } \\
\text { sekitarnya, dan mengembangkan upaya-upaya } \\
\text { untuk memperbaiki kerusakan alam yang } \\
\text { sudah terjadi. }\end{array}$ \\
\hline 18. & Tanggung jawab & $\begin{array}{l}\text { Sikap dan perilaku seseorang untuk } \\
\text { melaksanakan tugas dan kewajibannya, yang } \\
\text { seharusnya dia lakukan, terhadap diri sendiri, } \\
\text { masyarakat, lingkungan (alam, sosial dan } \\
\text { budaya), negara dan Tuhan Yang Maha Esa }\end{array}$ \\
\hline
\end{tabular}

\section{F. Urgensi Pendidikan Karakter}

Pembentukan karakter pada setiap subjek didik merupakan tujuan dari pendidikan nasional, hal ini sesuai dengan Pasal 3 Undang-undang Sidiknas no. 20 tahun 2003 menyatakan bahwa tujuan pendidikan nasional adalah mengembangkan potensi subjek didik agar menjadi manusia yang beriman dan bertakwa kepada Tuhan Yang Maha Esa, berakhlak mulia, sehat, berilmu, cakap, kreatif, mandiri, dan menjadi warganegara yang demokratis serta bertanggung jawab. $^{29}$ Pesan dari Undang-undang Sidiknas tahun 2003 tersebut bermaksud agar pendidikan tidak hanya membentuk insan Indonesia yang pandai, tetapi juga memiliki keperibadian atau berkarakter, sehingga nantinya lahir generasi bangsa yang tidak hanya memiliki kemampuan aspek pengetahuan yang baik, namun memiliki generasi yang berkembang dengan karakter yang bernafaskan moral yang baik, nilai-nilai luhur bangsa serta beragama.

\footnotetext{
${ }^{29}$ Undang-Undang Republik Indonesia Nomor 20 Tahun 2003 tentang Sistem Pendidikan Nasional.Bab II, Pasal 3: tentang Dasar, Fungsi, dan Tujuan Pendiikan Nasional.
}

Jurnal Pendidikan Agama Islam 
Pendidikan karakter dapat dimaknai sebagai pendidikan budi pekerti yaitu yang melibatkan aspek pengetahuan (cognitive), sikap perasaan (affection felling), dan tindakan (action). Menurut Thomas Lickona dalam Bambang Soenarko tanpa ketiga aspek tersebut, pendidikan karakter tidak akan efektif. ${ }^{30}$ Dengan pendidikan karakter yang diterapkan secara sistematis dan berkelanjutan, seorang subjek didik akan menjadi cerdas emosinya. Kecerdasan emosi ini adalah bekal penting menyongsong anak dalam meraih masa depan, karena seseorang akan lebih mudah dan berhasil menghadapi segala macam tantangan kehidupan, termasuk tantangan untuk berhasil secara akademis. ${ }^{31}$

Dasar pendidikan karakter ini, sebaiknya diterapkan sejak usia kanak-kanak atau yang biasa disebut para ahli psikologi sebagai usia emas (golden age), sesuai dengan usia anak sekolah dasar menurut Piaget pada tahap operasional kongkrit. karena usia ini terbukti sangat menentukan kemampuan anak dalam mengembangkan potensinya. Dari sini, sudah sepatutnya pendidikan karakter dimulai dari dalam keluarga dan sekolah, yang merupakan lingkungan pertama bagi pertumbuhan karakter anak. Menurut Suyanto pertumbuhan kecerdasan otak manusia yang paling besar terjadi pada masa anak-anak.

Menurut Menteri Pendidikan Indonesia Muhammad Nuh karakter seseorang dalam proses perkembangan dan pembentukannya dipengaruhi oleh dua faktor, yaitu faktor lingkungan (nurture) dan faktor bawaan (nature). Tinjauan teoretis perilaku berkarakter secara psikologis merupakan

\footnotetext{
30 Bambang Soenarko, Konsep Pendidikan Karakter (Kediri: Universitas Nusantara PGRI Kediri, 2010), 43

31 Masnur Muslich, Pendidikan Karakter: Menjawab Tantangan Krisis Multidimensional, 29-30.
} 
perwujudan dari potensi Intellegence Quotient (IQ), Emotional Quentient (EQ), Spritual Quotient (SQ) dan Adverse Quotient (AQ) yang dimiliki oleh seseorang. ${ }^{32}$ Sedangkan seseorang yang berkarakter menurut pandangan agama pada dirinya terkandung potensi-potensi, yaitu: sidiq, amanah, fathonah, dan tablig. ${ }^{33}$ Berkarakter menurut teori pendidikan apabila seseorang memiliki potensi kognitif, afektif, dan psikomotor yang teraktualisasi dalam kehidupannya. Adapun menurut teori sosial, seseorang yang berkarakter mempunyai logika dan rasa dalam menjalin hubungan intra personal, dan hubungan interpersonal dalam kehidupan bermasyarakat.

Perilaku seseorang yang berkarakter pada hakekatnya merupakan perwujudan fungsi totalitas psikologis yang mencakup seluruh potensi individu manusia (kognitif, afektif, konatif, dan psikomotorik) dan fungsi totalitas sosial kultural dalam konteks interaksi (dalam keluarga, satuan pendidikan, dan masyarakat) dan berlangsung sepanjang hayat. ${ }^{34}$

\section{G. Strategi Implementasi Pendidikan Karakter}

Marten mengusulkan tentang strategi implementasi pendidikan karakter yang efektif, yakni harus dilakukan secara lebih konkret. Ada tiga tahapan yang perlu dilakukan dalam implementasi pendidikan karakter, yakni: identifikasi nilai, pembelajaran nilai, dan memberikan kesempatan untuk menerapkan nilai tersebut. ${ }^{35}$

\footnotetext{
${ }^{32}$ Kemdiknas, Desain Induk Pendidikan Karakter, 9-10.

${ }^{33}$ E. Mulyasa, Mangemen Pendidikan Karakter, 5.

${ }^{34}$ Kemdiknas, Desain Induk Pendidikan Karakter, 8.

35 R. Marten, Successful Coaching (Edisi Ketiga), (Champaign, IL: Human Kinetics, 2004), 58.
} 


\section{Identifikasi Nilai}

Identifikasi nilai terkait dengan nilai-nilai moral apa saja yang sekurang-kurangnya harus dimiliki oleh individu. Dalam realitas kehidupan, ada sejumlah nilai yang terkonstruksi di dalam masyarakat yang boleh jadi antara masyarakat yang satu dengan yang lain berbeda. Ada kalanya konstruksi nilai dipengaruhi oleh kultur tempat nilai tersebut dibentuk. Karena itu, untuk menghindari pemahaman yang berbeda atas suatu nilai, perlu diidentifikasi dulu nilai-nilai yang berlaku universal atau yang ditargetkan.

\section{Pembelajaran Nilai}

Setelah proses identifikasi nilai dilakukan dan ditemukan nilai moral yang ditargetkan, nilai moral tersebut selanjutnya ditanamkan kepada subjek didik melalui langkah-langkah sebagai berikut.

a. Menciptakan lingkungan yang memungkinkan nilai-nilai moral tersebut diterapkan. Peran ini begitu penting dilakukan oleh seorang pendidik dalam rangka membangun kesamaan wawasan mencapai tujuan, menciptakan iklim moral bagi subjek didik.

b. Adanya keteladanan atau model perilaku moral. Menunjukkan perilaku bermoral memiliki dampak yang lebih kuat daripada berkata-kata tentang moral. One man practicing good sportmanship is better than fifty others preaching it.

c. Menyusun aturan atau kode etik berperilaku baik. Subjek didik perlu mengetahui apa yang boleh dan tidak boleh dilakukan.Artinya, ada pemahaman yang sama terkait dengan perilaku moral. 
d. Menjelaskan dan mendiskusikan perilaku bermoral. Ketika usia anak-anak, belajar perilaku moral dilakukan dengan cara imitasi dan praktik tanpa harus mengetahui alasan mengapa hal itu dilakukan atau tidak dilakukan. Memasuki usia remaja dan dewasa, kemampuan bernalarnya telah berkembang. Karena itu, perlu ada penjelasan dan bila perlu ada proses diskusi untuk sampai pada pilihan perilaku moral yang diharapkan.

e. Menggunakan dan mengajarkan etika dalam pengambilan keputusan. Individu acapkali dihadapkan pada pilihanpilihan yang harus diambil keputusannya. Mengambil keputusan adalah proses mengevaluasi tindakan-tindakan dan memilih alternatif tindakan yang sejalan dengan nilai moral tertentu.

f. Mendorong individu subjek didik mengembangkan nilai yang baik. Seorang pendidik perlu menciptakan situasi dan menginspirasi subjek didik untuk menampilkan perilaku moral. A mediocre teacher tells, a good teacher explains, a superior teacher demonstrates, and the great teacher inspires.

\section{Penerapan Nilai}

Setelah pembelajaran nilai dilakukan, tahap ketiga yang perlu dilakukan adalah memberikan kesempatan untuk mengaplikasikannya. Hal terpenting bertalian dengan penerapan nilai adalah konsistensi antara apa yang diajarkan dengan apa yang diterapkan. Artinya, apa yang dikatakan harus berbanding lurus dengan apa yang dilakukan, baik pada lingkungan sekolah, kampus maupun dalam keluarga dan masyarakat. Terkait dengan penerapan nilai, ada dua model yang dapat diaplikasikan. Pertama, membentuk kebiasaan rutin yang bermuatan nilai-nilai 
moral. Kedua, memberikan reward bagi subjek didik yang menampilkan perilaku bernilai moral. Menanamkan dan membentuk nilai moral memang tidak secepat mengajarkan keterampilan seperti menendang atau memukul bola. Untuk hal tersebut dibutuhkan proses yang relatif panjang, konsisten, dan tidak sekali jadi. Bisa jadi subjek didik belum sepenuhnya menampilkan perilaku bernilai moral sebagaimana yang diinginkan. Karena itu, penghargaan tidak harus diberikan ketika subjek didik mengakhiri serangkaian kegiatan, melainkan juga dalam proses "menjadi". Penghargaan dapat diberikan dalam berbagai bentuk. Misalnya, dalam bentuk sertifikat, stiker, peran tertentu seperti mentor bagi temannya, dan lain sebagainya.

Zuchdi mengemukakan supaya pendidikan moral/nilai atau pendidikan karakter) tidak bersifat indoktrinatif, subjek didik perlu didorong untuk dapat menemukan alasan-alasan yang mendasari keputusan moral. Tujuannya untuk mengembangkan kemampuan mengontrol tindakan yang diperlukan agar seseorang dapat benar-benar memahami keputusan moral yang diambilnya, dapat mengidentifikasi alasan yang baik yang harus diterima dan alasan yang tidak baik yang harus ditolak atau diubah. Pada akhirnya subjek didik harus mampu merumuskan perubahan yang perlu dilakukan. Pembelajaran mestinya menciptakan setting sosial yang memungkinkan implementasi pengetahuan yang diperoleh untuk memecahkan masalah yang ada dalam masyarakat. Selanjutnya, pendidikan moral/nilai hendaknya difokuskan pada kaitan antara pemikiran moral (moral thinking) dan tindakan bermoral (moral action). Konsep moralitas perlu diintegrasikan dengan pengalaman dalam kehidupan sosial. Pemikiran moral dapat dikembangkan antara lain dengan 
dilema moral yang menuntut kemampuan untuk mengambil keputusan dalam situasi yang sangat dilematis. Tindakan moral yang selaras dengan pemikiran moral hanya mungkin dicapai bila subjek didik berkesadaran moral dan memilki kencerdasan emosional dan spiritual serta pembiasaan. ${ }^{36}$

\section{H. Desain Pendidikan Karakter Berbasis Kecerdasan dan Kasadaran Moral}

Karakter adalah cara berpikir dan berperilaku yang menjadi ciri khas tiap individu untuk hidup dan bekerjasama, baik dalam lingkup keluarga, masyarakat dan negara. Individu yang berkarakter baik adalah individu yang bisa membuat keputusan dan siap mempertanggungjawabkan akibat dari keputusan yang dibuatnya. Pendidikan karakter pada hakikatnya adalah pendidikan nilai yang melibatkan aspek pengetahuan (cognitive), perasaan (feeling), dan tindakan (action). Lickona mengemukakan bahwa pendidikan nilai/moral yang menghasilkan karakter, didalamnya terkandung tiga komponen karakter yang baik (components of good character), yakni: pengetahuan tentang moral (moral knowing), perasaan tentang moral (moral feeling) dan perbuatan moral (moral action) sebagaimana terlihat pada Gambar 1.37

\footnotetext{
${ }^{36}$ Darmiyati Zuchdi, Humanisasi Pendidikan: Menemukan Kembali Pendidikan Yang Manusiawi, (Jakarta: PT. Bumi Aksara, 2008), 6-8.

${ }^{37}$ Muclas Samani, dan Hariyanto, Konsep dan Model Pendidikan Karakter, 50. Lihat juga Dharma Kesuma, dkk, Pendidikan Karakter: Kajian Teori dan Praktek di Sekolah, (Bandung: PT Remaja Rosdakarya, 2013), 70.
}

Jurnal Pendidikan Agama Islam 


\section{Gambar 1: Komponen Pendidikan Karakter yang Baik}

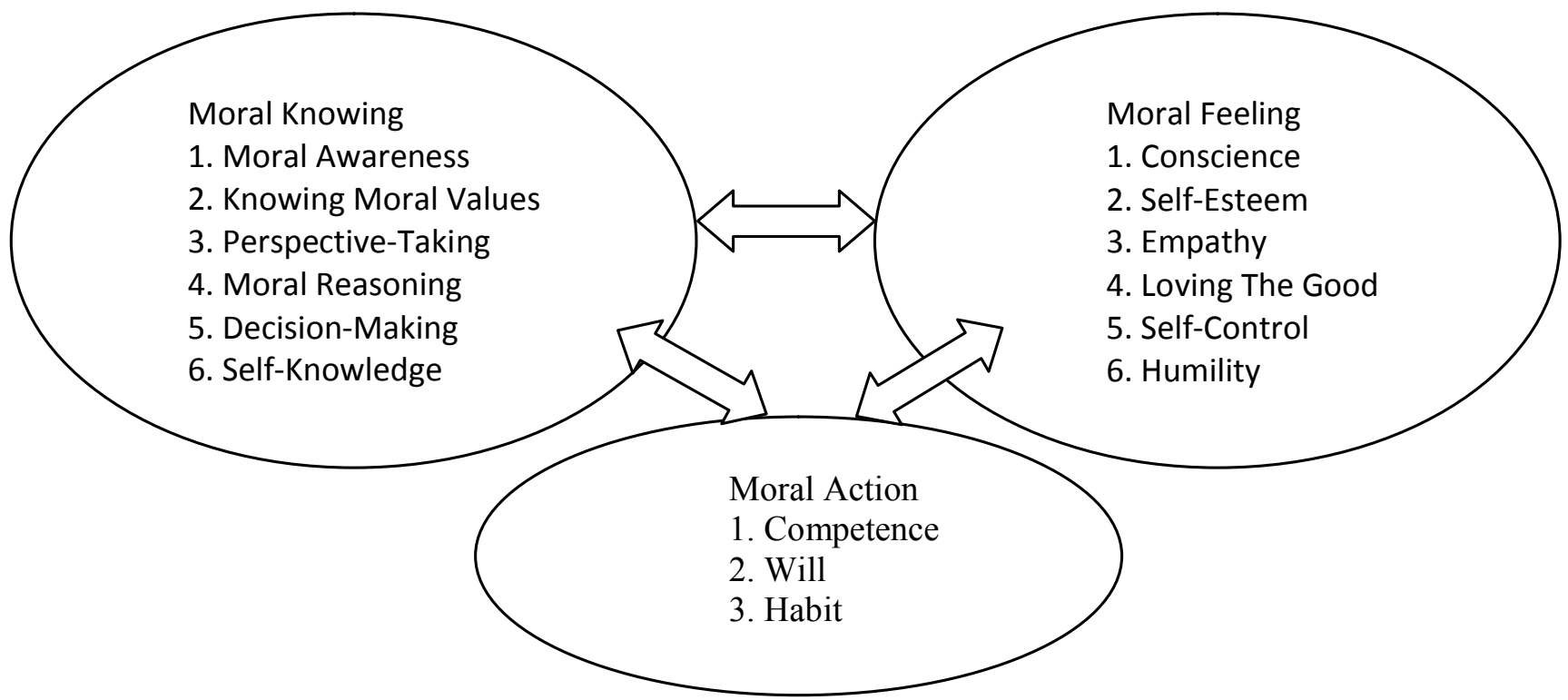

Anak panah yang menghubungkan masing-masing domain karakter dan kedua domain karakter lainnya ditekankan untuk menekankan sifat saling berhubungan masing-masing domain tersebut, pengetahuan moral (moral knowing), perasaan moral (moral feeling), dan tindakan moral (moral action) tidak berfungsi sebagai bagian yang terpisah namun saling melakukan penetrasi dan saling mempengaruhi satu sama lain dalam cara apapun. ${ }^{38}$

Ketiga komponen pada Gambar 1 dalam aplikasi pendidikan karakter harus terbangun secara terkait. pengetahuan moral (moral knowing) yang meliputi: kesadaran moral, pengetahuan nilai-moral, pandangan ke depan, penalaran moral, pengambilan keputusan dan pengetahuan diri, adalah hal esensial yang perlu diajarkan kepada subjek didik yang mana sebagai generasi penerus bangsa.

\footnotetext{
${ }^{38}$ Thomas Lickona, Educating for Character: How Our School Can Teach Respect and Responsibility, terj. Mendidik Untuk Membentuk Karakter:Bagaimana Sekolah dapat Memberikan Pendidikan tentang Sikap Hormat dan Tanggung Jawab, Juma Abdu Wamaungo (Penerj.), (Jakarta: Bumi Aksara, 2012), 84-85.
} 
Namun, pendidikan karakter sebatas pengetahuan moral (moral knowing) tidaklah cukup. Untuk itu perlu berlanjut sampai pada perasaan moral (moral feeling yang meliputi: kata hati, rasa percaya diri, empati, cinta kebaikan, pengendalian diri dan kerendahan hati. Bahkan terus berlanjut pada tahap yang paling penting, yakni tindakan moral (moral action). Disebut penting karena pada tahap ini motif dorongan seseorang untuk berbuat baik, tampak pada aspek kompetensi, keinginan dan kebiasaan yang ditampilkannya.

Ketersusunan tiga komponen moral yang saling berhubungan secara sinergis, menjadi syarat mutlak aktualisasi pendidikan karakter dalam mengembangkan kecerdasan dan kesadaran moral generasi bangsa (subjek didik). Kesadaran moral adalah kemampuan memahami hal yang benar dan yang salah dengan keyakinan etika yang kuat dan bertindak berdasarkan keyakinannya tersebut dengan sikap yang benar serta perilaku yang terhormat dan sesuai dengan prinsip moralitas yang ada. Pendidikan karakter menjadi sesuatu yang urgen dalam membentuk generasi yang berkesadaran moral, karena pendidikan karakter merekonstruksi kembali dan membangun moral generasi bangsa dalam menyikapi dan menghadapi tantangan hidup di masa yang akan datang yang penuh dengan kontradiktif.

Lebih lanjut, Borba menguraikan tujuh kebajikan utama yang perlu dimiliki generasi bangsa (subjek didik) dalam mengembangkan kecerdasan dan kesadaran moral, yakni: empati, hati nurani, control diri, rasa hormat, kebaikan hati, toleransi, dan keadilan. Dengan desain pendidikan karakter berbasis kecerdasan dan kesadaran moral yang diaktualisasikan secara sistematis dan berkelanjutan ini, subjek didik akan memiliki sejumlah kebajikan utama yang berguna bagi dirinya dalam menghadapi segala macam tantangan 
kehidupan, termasuk tantangan untuk berhasil secara akademis. Dengan demikian, pendidikan karakter berbasis kecerdasan dan kesadaran moral merupakan upaya pengembangan kemampuan generasi penerus bangsa yang berorientasi pada pemilikan kompetensi kecerdasan plus karakter serta berkesadaran moral. ${ }^{39}$

Agar pendidikan karakter dapat membentuk generasi bangsa yang berkesadaran moral, maka perlu digunakan desain pengkondisian moral (moral conditioning) sebagai tahap awal implementasi. ${ }^{40}$ Menurut Lickona ${ }^{41}$, ada sebelas prinsip agar pendidikan karakter dapat terlaksana secara efektif: (1) mengembangkan nilai-nilai universal sebagai fondasi; (2) mendefenisikan karakter secara komprehensif yang mencakup aspek pikiran, perasaan dan perilaku; (3) menggunakan pendekatan yang komprehensif dan proaktif; (4) menciptakan komunitas sekolah yang penuh perhatian; (5) memberi kesempatan kepada subjek didik untuk melakukan tindakan moral; (6) membuat kurikulum akademik yang bermakna; (7) mendorong motivasi subjek didik; (8) melibatkan seluruh komponen sekolah sebagai komunitas pembelajaran moral; (9) menumbuhkan kebersamaan dalam kepemimpinan moral; (10) melibatkan keluarga dan anggota masyarakat sebagai mitra; dan (11) mengevalusi karakter sekolah baik terhadap staf sekolah sebagai pendidik karakter maupun subjek didik dalam memanifestasikan karakter yang baik.

${ }^{39}$ Borba, Michele. Buiding Moral Inteligence, The Seven Essential Virtues that Teach Kidsto do The Right Thing, Tert. "Membangun Kecerdasan Moral, Tujuh Kebajikan Utama untuk Membentuk Anak Bermoral Tinggi", Lina Yusuf (Penerj.), (Jakarta: Gramedia, 2008), 4-7.

40 Zubaedi, Desain Pendidikan Karakter Konsepsi dan Aplikasinya dalam Lembaga Pendidikan, 30.

${ }^{41}$ Thomas Lickona, Educating for Character: How Our Schools can Teach Respect and Responsibility, 187-189. 
Desain pengkondisian moral di atas, pada konteks mikro mensyaratkan pendidikan karakter di sekolah dapat diaktualisasikan melalui empat pilar, yakni: (1) kegiatan belajar mengajar di kelas, dengan mengimplementasikan pendidikan karakter yang menggunakan pendekatan terintegrasi dalam semua mata pelajaran (embedded approach); (2) kegiatan keseharian dalam bentuk penciptaan budaya sekolah (school culture); (3) kegiatan ko-kurikuler dan atau ekstrakurikuler; dan (4) kegiatan keseharian di rumah dan dalam masyarakat. ${ }^{42}$

Desain ini menunjukkan bahwa dalam pendidikan karakter mengharuskan adanya tiga basis desain dalam pemrogramannya yang terbagi menjadi sebagai berikut. Pertama, desain pendidikan karakter berbasis kelas. Desain ini berbasis pada relasi guru sebagai pendidik dan subjek didik sebagai pembelajar di dalam kelas. Konteks pendidikan karakter adalah proses relasional komunitas kelas dalam konteks pembelajaran. Kedua, desain pendidikan karakter berbasis kultur sekolah. Desain ini mencoba membangun kultur sekolah yang mampu membentuk karakter subjek didik dengan bantuan pranata sosial sekolah agar nilai tertentu terbentuk dan terbatinkan dalam diri subjek didik. Ketiga, desain pendidikan karakter berbasis komunitas. Dalam mendidik, komunitas sekolah tidak berjuang sendirian. Masyarakat di luar lembaga pendidikan, seperti keluarga, masyarakat umum, dan negara, juga memiliki tanggung jawab moral untuk mengintegrasikan pembentukan karakter dalam konteks kehidupan subjek didik.

Pendidikan karakter hanya akan bisa efektif jika tiga desain pendidikan karakter ini dilaksanakan secara simultan dan sinergis. Melalui desain seperti ini, diharapkan pendidikan

\footnotetext{
42 Ibid., 220-221. Lihat juga Masnur Muslich, Pendidikan Karakter: Menjawab Tantangan Krisis Multidimensional, 133-136.
}

Jurnal Pendidikan Agama Islam

Volume 02 Nomor 02 November 2014

Hal $418-426$ 
karakter dapat berperan dalam mengembangkan kesadaran moral generasi penerus bangsa secara komprehensif dan berkelanjutan.

\section{Moral Training sebagai Strategi Pengembangan dan Pembentuk Generasi yang Berkesadaran Moral}

Pengondisian moral sebagai tahap awal implementasi pendidikan karakter pada konteks mikro, perlu dilanjutkan ke tahap latihan moral (moral training). Namun pengkondisian moral dalam pendidikan karakter belum sempurna, manakala desain pendidikan karakter berbasis kelas masih didominasi pembelajaran konvensional. Artinya, sebaik apa pun pengkondisian moral dirancang dalam rangka mengimplementasikan pendidikan karakter berbasis kesadaran moral, tidak akan efektif jika kegiatan belajar-mengajar di kelas guru masih menampilkan ciri: teacher centered, dominasi ekspositori, berorientasi tekstual, berorientasi pada kognitif tingkat rendah dan transfer of knowledge. Desain moral training dalam mengembangkan kesadaran moral, menuntut bergesernya pembelajaran konvensional ke arah pembelajaran inovatif. Mengapa demikian? Karena pendidikan karakter dengan pola pembelajaran konvensional, hanya akan mengajarkan pendidikan moral sebatas tekstual semata dan kurang mempersiapkan subjek didik untuk menyikapi kehidupan yang kontradiktif. ${ }^{43}$

Untuk itu, sekolah sebagai salah satu pengemban pendidikan karakter yang membentuk generasi berkeasadaran moral sudah saatnya berbenah secara kreatif mengembangkan pembelajaran inovatif. Pergesaran pembelajaran konvensional

43 Zubaedi, Desain Pendidikan Karakter Konsepsi dan Aplikasinya dalam Lembaga Pendidikan, 2. 
ke arah pola pembelajaran inovatif menjadi syarat dalam pendidikan karakter untuk dapat mengembangkan kesadaran moral secara efektif. Pergeseran yang dimaksud, dapat ditampilkan seperti pada Tabel di bawah ini.

\section{Tabel 2:}

Pergeseran Pembelajaran Konvensional ke Pembelajaran Inovatif

\begin{tabular}{|l|l|}
\hline Pembelajaran Konvensional & Pembelajaran Inovatif \\
\hline Pendekatan Teacher Centered & Pendekatan Student Centered \\
\hline Dominasi Ekspositori & Multi model dan metode \\
\hline Minim media & Multimedia \\
\hline Textbook Center & Multi sumber belajar \\
\hline Pembelajaran Verbalistik & Pembelajaran Konstektual \\
\hline $\begin{array}{l}\text { Evaluasi dominasi kognitif tingkat } \\
\text { rendah (C1, C2) }\end{array}$ & $\begin{array}{l}\text { Evaluasi: Kognitif, Afektif dan } \\
\text { Psikomotor }\end{array}$ \\
\hline $\begin{array}{l}\text { Posisi guru sebagai transfer of } \\
\text { knowledge }\end{array}$ & $\begin{array}{l}\text { Posisi guru sebagai director of } \\
\text { learning }\end{array}$ \\
\hline
\end{tabular}

Pembelajaran inovatif dalam pendidikan karakter dirancang untuk menghasilkan kegiatan belajar-mengajar yang lebih efektif dan bermakna. Pembelajaran inovatif menjadi kondisi kondusif dalam melatih moral untuk mengembangkan kecerdasan dan kesadaran moral subjek didik. Moral training merupakan bagian strategi pengembangan dan pembentuk generasi yang berkesadaran moral. Melalui moral training, pendidikan karakter tidak terhenti sebatas moral knowing tetapi berlanjut pada tahap moral feeling dan moral action yang secara sinergis berkontribusi terhadap pengembangan kesadaran moral subjek didik. Penerapan moral training dalam pembelajaran inovatif pada pendidikan berbasis karakter diharapkan dapat: (1) mengembangkan dan membentuk kesadaran moral generasi bangsa (subjek didik) secara 
komprehensif; (2) memberi pengalaman belajar bervariasi dengan suasana belajar yang menyenangkan; (3) subjek didik menjadi lebih kritis dan kreatif; (4) meningkatkan kematangan emosional; dan (5) mau berpartisipasi dalam proses perubahan. Moral training menjadi lebih penting, ketika dikaitkan dengan tujuan pendidikan moral yang hendak dicapai.

Frankena mengemukakan bahwa tujuan pendidikan moral mencakup: (1) membantu subjek didik untuk dapat mengembangkan tingkah-laku yang secara moral baik dan benar; (2) membantu subjek didik untuk dapat meningkatkan kemampuan refleksi secara otonom, (3) membantu subjek didik untuk menginternalisasikan nilai-nilai moral, normanorma dalam menghadapi kehidupan konkretnya; (4) membantu subjek didik untuk mengadopsi prinsip-prinsip universal, nilai-nilai kehidupan sebagai pijakan untuk pertimbangan moral dalam menentukan suatu keputusan; dan (5) membantu subjek didik untuk mampu membuat keputusan yang benar, bermoral, dan bijaksana (6) Serta membentuk subjek didik (generasi penerus bangsa) berkesadaran moral. ${ }^{44}$.

\section{J. Penutup}

Pendidikan formal sebagai wahana sistemik pembangunan karakter anak bangsa belumlah memberikan output (keluaran) yang optimal terhadap pembentukan dan pengembangan kesadaran moral generasi penerus bangsa (subjek didik). Hal ini diduga karena dunia pendidikan hingga saat ini lebih cenderung mementingkan pencapaian kompetensi akademik ketimbang pencapaian kompetensi

\footnotetext{
44 J.R.S. Adisusilo, Pembelajaran Nilai Karakter. (Jakarta: PT. Raja Grafindo Persada, 2012), 128.
} 
karakter. Untuk itu, usulan adanya pendidikan karakter yang teraktualisasikan secara integralistik sebagai wahana sistemik pengembangan kesadaran moral generasi penerus bangsa perlu mendapat dukungan berbagai pihak dalam menghasilkan output (luaran) generasi penerus bangsa yang memiliki kompetensi kecerdasan plus karakter dan berkesadaran moral.

Usulan ini menuntut pendidikan formal sebagai pengemban pendidikan karakter, melakukan upaya keratif dengan menggeser pembelajaran konvensional ke arah pembelajaran inovatif. Pendidikan karakter dengan pola pembelajaran konvensional, hanya akan mengajarkan pendidikan moral sebatas tekstual semata dan kurang mempersiapkan peserta didik (subjek didik) untuk menyikapi kehidupan yang kontradiktif. Dengan demikian dalam konteks mikro, pola pembelajaran inovatif menjadi syarat utama dalam mengaplikasikan pendidikan karakter untuk dapat mengembangkan kecerdasan dan kesadaran moral secara efektif.

Menghadapi tuntutan di atas, untuk mengoptimalisasikan pendidikan karakter dalam mengembangkan generasi yang berkesadaran moral maka diperlukan strategi Implementasi pendidikan karakter yang mana meliputi indentifikasi nilai, pembelajaran nilai, dan penerapan nilai. Dengan stratregi implementasi pendidikan karakter ini diharapkan terjadi proses karakterisasi dan konstruksisasi kembali moral generasi penerus bangsa. Implikasinya, pendidikan formal sebagai institusi pengemban pendidikan karakter perlu melakukan pembenahan diri. Desain peran pendidikan karakter dengan pola integralistik dalam mengembangkan kesadaran moral generasi penerus bangsa akan berjalan efektif dan bermakna, melalui upaya kreatif pihak sekolah dalam merancang pengkondisian moral (moral 
conditioning) dan aplikasinya, yaitu latihan moral (moral training) secara komprehensif, sistemik dan berkelanjutan. Dengan segala tahap dan proses diatas, Pendidikan karakter akan menghasilkan output dan membentuk generasi penerus bangsa yang berkesadaran moral. 


\section{DAFTAR PUSTAKA}

Ahmad Amin, Etika (Ilmu Akhlak), Farid Ma'ruf (Penerj.) (Jakarta: Bulan Bintang, 1995).

Abdul Majid dan Dian Andayani, Pendidikan Karakter Perspektif Islam (Bandung: PT. Remaja Rosdakarya, 2012).

Borba, Michele. Buiding Moral Inteligence, The Seven Essential Virtues that Teach Kidsto do The Right Thing, Tert. "Membangun Kecerdasan Moral, Tujuh Kebajikan Utama untuk Membentuk Anak Bermoral Tinggi", Lina Yusuf (Penerj.), (Jakarta: Gramedia, 2008).

Bambang Soenarko, Konsep Pendidikan Karakter (Kediri: Universitas Nusantara PGRI Kediri, 2010).

Dharma Kesuma, dkk, Pendidikan Karakter: Kajian Teori dan Praktek di Sekolah, (Bandung: PT Remaja Rosdakarya, 2013).

Darmiyati Zuchdi, Humanisasi Pendidikan: Menemukan Kembali Pendidikan Yang Manusiawi, (Jakarta: PT. Bumi Aksara, 2008).

Doni A. Koesoema, Pendidikan Karakter: Strategi Mendidik Anak di Zaman Global (Jakarta: Grasindo, 2007).

E.J. Hobsbawm, The Invention of Tradition (New York: Cambridge University Press, 1983).

E. Mulyasa, Mangemen Pendidikan Karakter (Jakarta: PT Bumi Aksara, 2012).

E.F Schaeffer, It's Time for Schools To Implement Character Education, NASSP Bulletin, 1999.

Holly Shepard Salls, Character Education: An Introduction (New York: University Press of America, 2007).

John M. Echols dan Hassan Shadily, Kamus Inggris-Indonesia (Jakarta: Gramedia, 2003). 
J.R.S. Adisusilo, Pembelajaran Nilai Karakter (Jakarta: PT. Raja Grafindo Persada, 2012).

Kemdiknas, Desain Induk Pendidikan Karakter (Jakarta: Kementerian Pendidikan Nasional, 2010).

Kementrian Pendidikan Nasional Badan Penelitian dan Pengembangan Pusat Kurikulum. Bahan Pelatihan Penguatan Metodologi Pembelajaran Berdasarkan NilaiNilai Budaya Untuk Membentuk Daya Saing Dan Karakter Bangsa. Pengembangan Pendidikan dan Karakter Bangsa. (Jakarta: Kemendiknas, 2010).

Kemko Kesejahteraan Rakyat, Kebijakan Nasional Pembangunan Karakter Bangsa (Jakarta: Kemko Kesejahteraan Rakyat, 2010).

Kevin Ryan dan K. E Bohlin, Building Character in Schools: Practical Ways to Bring Moral Instruction to Life (San Francisco: Jossey Bass, 1999).

Mike Frye, Character Education: Informational Handbook and Guide for Support and Implementation of the Student Citizent Act of 2001 (North Carolina: Public Schools of North Carolina, 2002).

Masnur Muslich, Pendidikan Karakter: Menjawab Tantangan Krisis Multidimensional (Jakarta: PT. Bumi Aksara, 2011).

Pusat Bahasa Depdiknas, Kamus Bahasa Indonesia (Jakarta: Pusat Bahasa, 2008), 639. Lihat juga Muclas Samani, dan Hariyanto, Konsep dan Model Pendidikan Karakter (Bandung: PT. Remaja Rosdakarya, 2012).

R. Marten, Successful Coaching (Edisi Ketiga), (Champaign, IL: Human Kinetics, 2004).

Suyadi, Strategi Pembelajaran Pendidikan Karakter (Bandung: PT Remaja Rosdakarya, 2013).

Sekretariat Negara Republik Indonesia, Undang-Undang RI Nomor 17 Tahun 2007 tentang Rencana Pembangunan Jangka 
Panjang 2005-2025 (Jakarta: Sekretariat Negara RI, 2007), Bab IV: tentang Arahan, Tahapan, dan PrioritasPembangunan Jangka Panjang 2005-2025.

Thomas Lickona, Educating for Character: How Our School Can

Teach Respect and Responsibility (New York: Bantam Books, 1991).

Thomas Lickona, Educating for Character: How Our School Can

Teach Respect and Responsibility, terj. Mendidik Untuk Membentuk Karakter:Bagaimana Sekolah dapat Memberikan Pendidikan tentang Sikap Hormat dan Tanggung Jawab, Juma Abdu Wamaungo (Penerj.), (Jakarta: Bumi Aksara, 2012).

Undang-Undang Republik Indonesia Nomor 20 Tahun 2003 tentang Sistem Pendidikan Nasional.Bab II, Pasal 3: tentang Dasar, Fungsi, dan Tujuan Pendiikan Nasional.

Zubaedi, Desain Pendidikan Karakter Konsepsi dan Aplikasinya dalam Lembaga Pendidikan, (Jakarta: Kencana, 2011).

Zainuddin, Reformasi Pendidikan: Kritik Kurikulum dan Manajemen Berbasis Sekolah (Yogyakarta: Pustaka Pelajar, 2008). 